11. Soleri P. Arcology: The City in the Image of Man. Cosanti Press; 4th edition, 2006. - 136p.

12. Pearson D. New Organic Architecture: The Breaking Wave. Berkeley, University of California Press, 2001; Cyberspace. The world of digital architecture. The Images Publishing Group Pty Ltd, Australia, 2001.

13. Spiller N. Digital Dreams: Architecture and the New Alchemic Technologies, New York, Whitney Library of Design, 1998; Idem. Visionary Architecture: Blueprints of the Modern Imagination. London, Thames and Hudson, 2006; Idem. Digital Architecture NOW. London, Thames and Hudson, 2008.

14. Tsui E. Evolutionary architecture: nature as a basis for design. N. Y.; L., 1999.

15. Park, J. J. \& Dave, B. Bio-inspired Parametric Design of Adaptive Stadium Facades, Australasian Journal of Construction Economics and Building Conference Series, 2014, 2(2), 27-35.

Sopov D.V., Mironenko V.P. CONCEPTUAL MODEL OF THE FUTURE ECOPOLIS. The implementation of the principle of sustainable development is considered on the example of existing and projected eco-settlements in the modern world. The main conceptual principles of the formation of eco-settlements are identified from the standpoint of the features of ideology, ecology, urban planning, life support and architecture. A classification and typology of eco-settlements is presented, taking into account their development and changes in life-support technologies and architectural design. The role of eco-settlements in the modern world and their social significance in creating a new type of society is shown.

Keywords: ecovillage, ecopolis, sustainable development, smart city, architectural and urban planning space.

Сопов Д.В., Мироненко В.П. КОНЦЕПТУАЛЬНА МОДЕЛЬ ЕКОПОЛІСУ МАЙБУТНЬОГО. Розглянуто реалізація принципу сталого розвитку на прикладі існуючих і проектіруемих екопоселень в умовах сучасного світу. Виявлено основні концептуальні принципи формування екопоселень 3 позицій особливостей ідеології, екології, містобудівництва, життєзабезпечення та архітектури. Представлена класифікація і тіпологізація екопоселень 3 урахуванням їх розвитку та змін в технологіях життєзабезпечення і архітектурного проектування. Показана роль екопоселень в сучасному світі і їх соціальне значення в створенні нового типу суспільства.

Ключові слова: екопоселення, екополіс, сталий розвиток, smart city, архітектурно-містобудівний простір.

DOI: $10.29295 / 2311-7257-2019-95-1-82-87$

УДК $72.01: 719$

\title{
Шарлай О.В.
}

Харківський національний університет будівництва і архітектури

(вул. Сумська, 40, Харків, 61002, Україна; email: Yasik_helene@i.ua; ORCID 0000-0003-1445-0339)

\section{РЕАЛІЗАЦІЯ КОНЦЕПЦІЇ ІНКЛЮЗИВНОГО МІСТА В СФЕРІ МІСЬКИХ КОМУНІКАЦЙ}

В статті наведені дані про стан захворювань зору за даними ВОЗ. Наведені принципи створення інклюзивного середовища і універсального дизайну для забезпечення доступності для всіх верств населення. Проаналізовані заходи по облаштуванню міського середовища для адаптації людей з особливими потребами, переважно - вадами зору. Наведено приклади закордонного досвіду облаштування міського середовища згідно концепції інклюзивного міста.

Ключові слова: інклюзивне місто, універсальний дизайн, адаптація, безбар'єрна архітектура, доступність міського середовища.

За даними Всесвітньої організації охорони здоров'я кількість сліпих людей в світі становить близько 40 мільйонів осіб, без урахування слабозрячих, які також ма- ють свої особливі потреби в повсякденному житті. В Україні за неофіційною статистикою (офіційні дані досі відсутні) сліпих людей налічується від 50 до 70 тисяч. 
В Харківській області в 2017році зареєстровано 17913 випадків захворювань на глаукому (662людини на 100 тисяч населення). За даними ВОЗ в світі налічується 135 мільйонів людей з вадами зору. Щороку кількість сліпих в світі зростає на 1-2 мільйони. За прогнозами до 2020 року в світі житиме понад 100 мільйонів сліпих, бо кожні 5 секунд втрачає зір 1 доросла людина, а кожну хвилину - 1 дитина. Для України ця проблема надзвичайно актуальна, оскільки дитяча сліпота і хвороби зору займають 4 місце серед причин інвалідності дітей в країні $[1,2]$.

Головною проблемою людей 3 порушеннями зору $є$ неповне сприйняття оточуючого середовища. Для того щоб мати можливість вільно пересуватись об'єктами соціальної інфраструктури, використовувати суспільний транспорт необхідно мати уяву про оточення. Незрячій людині важко орієнтуватись в просторі, тому вона повинна мати інші джерела інформації - звукові або тактильні. Такими людьми легше сприймаються об'єкти збільшеного масштабу, активна колірна палітра і яскраві кольорові поєднання, правильні і легкі для сприйняття композиційні форми, чорнобілі контрастні поєднання і особливо важливо наявність фактурних поверхонь [3].

Маючи інформацію про місце розташування людина зі слабким зором за допомогою тактильних покажчиків, світлофорів зі звукофонами, таблиць 3 текстом Брайля значно простіше орієнтується в просторі. Для сліпих і людей зі слабким зором «безбар'єрне середовище» - це не тільки спеціальні засоби соціально-середовищної адаптації, але і всім відомі пристосування, необхідні для всіх категорій населення (тротуари, бордюри, сходи, поручні). Проблема адаптації людей з особливими потребами полягає в тому,що впродовж довгого часу, до середини XX сторіччя, планування і забудова міст, інших населених пунктів, формування житлових і рекреаційних зон, а також розробка транспортних засобів не враховувала потреб людей 3 особливими вимогами.

Згідно нормативним документам до мало мобільних груп належать:
- інваліди з ураженням опорно-рухового апарату,

- інваліди з вадами зору і слуху,

- особи віком старше 60 років,

- тимчасово непрацездатні,

- вагітні жінки,

- люди $з$ дитячими візочками,

- діти дошкільного віку [4].

Таким чином, особливі потреби має значна кількість соціальних груп і тому все, що має бути зручним для інваліда, буде зручним і для всіх інших людей, незважаючи на те, що вони не мають особливих потреб.

Наприкінці XX сторіччя в архітектурі і містобудуванні формується запит на створення простору, який би задовольнив усіх. З'являється концепція інклюзивного міста і універсального дизайну, яка націлена на створення середовища що враховує потреби всіх відвідувачів незалежно від віку, соціального статусу або стану здоров'я. Головне завдання проектувальника - усунення бар'єрів і надання кожному можливості реалізувати власні плани діяльності. Автором концепції є американській архітектор і дизайнер Рональд Мейс і складається вона 37 основних принципів:

- рівні можливості для використання простору;

- гнучкість у використанні - різні уподобання, адаптація для шульги, можливість пересуватись різними темпами, використання аудіо- та відео- форматів;

- простота та інтуїтивність передбачає використання легкозрозумілого дизайнерського оточення;

- зрозуміла інструкція - передача інформації має здійснюватись легко та ефективно незважаючи на здібності користувача (вади слуху, зору, маломобільна людина чи іноземець);

- толерантність до помилок - небезпечні наслідки від помилки мають бути мінімізовані;

- мінімальні зусилля - ефективне використання всіх компонентів при незначних фізичних напруженнях[5].

На даний час в Україні поки відсутня цілеспрямована містобудівна політика по 
створенню інклюзивних міст. 35 українських міст зі списку кращих міст світу, жодне не відповідає вимогам людей із особливими запитами. Але перші результати прагнення до створення середовища яке б відповідало міжнародним стандартам надання сервісу та забезпечення доступності для всіх, реалізовані в аеропорту «Бориспіль»єдиному в Україні, де враховані вимоги до організації обслуговування різних категорій пасажирів. В Вінниці, Львові, Дніпрі з 2016 року розпочато облаштування тактильною плиткою тротуарів і зупинок суспільного транспорту.

В 2007 році в Україні затверджені Будівельні норми «Доступність будинків і споруд для маломобільних груп населення» ДБНВ.2.2-17:2006, де також реалізуються ідеї створення інклюзивного середовища. Так, у пункті 4.4 «Проектні рішення об'єктів, доступних для інвалідів, не повинні обмежувати умови життєдіяльності інших груп населення. 3 цією метою слід проектувати адаптовані до потреб інвалідів універсальні елементи ...які використовуються усіма групами населення. Необхідність застосування спеціалізованих елементів, що враховують специфічні потреби інвалідів, установлюється завданням на проектування», тобто мова йде про проектування. В умовах адаптації існуючого міського середовища дії мають відбуватись почергово [6]. Передусім необхідно встановити обладнання, що запобігає загрозам життю - облаштування тротуарів і пішохідних переходів, перонів станцій залізничного транспорту, підземних переходів. Для покращення інформаційно-комуникативного забезпечення передбачено дублювання візуальних табло, схем, повідомлень, та ін. перекладом 3 використанням шрифту Брайля.

Облаштування тротуарів. В Україні не тільки люди з вадами зору часто наражаються на небезпеку на вулицях, оскільки водії порушують норму паркування, передбачену правилами дорожнього руху, відносно обов'язкових двох метрів тротуару для пішоходів. Травматичні ситуації створюють також і автомобілі, що паркуються просто на пішохідному переході. Для фіксування межі території пішоходів використовують смуги з тактильної плитки. Таке облаштування не тільки полегшує пересування людям 3 вадами зору, а й допоможе орієнтуватись водієві, бо структурований простір транспортної інфраструктури дисциплінує і запобігає порушенням, убезпечує здоров'я пішоходів. Смуги тактильної плитки розташовують вздовж тротуару на відстані 0,8м. від бордюру (рис. 1, 2) [6, 7].

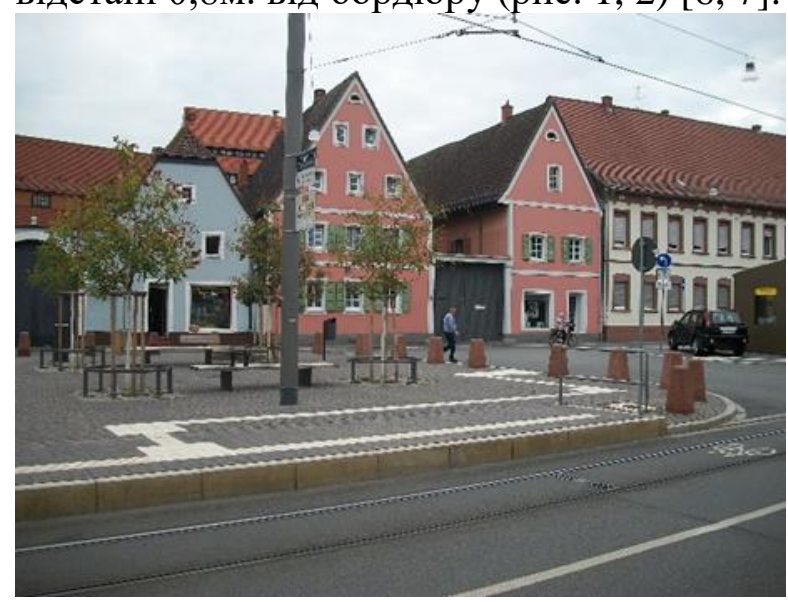

Рис. 1. Тротуарна тактильна смуга.

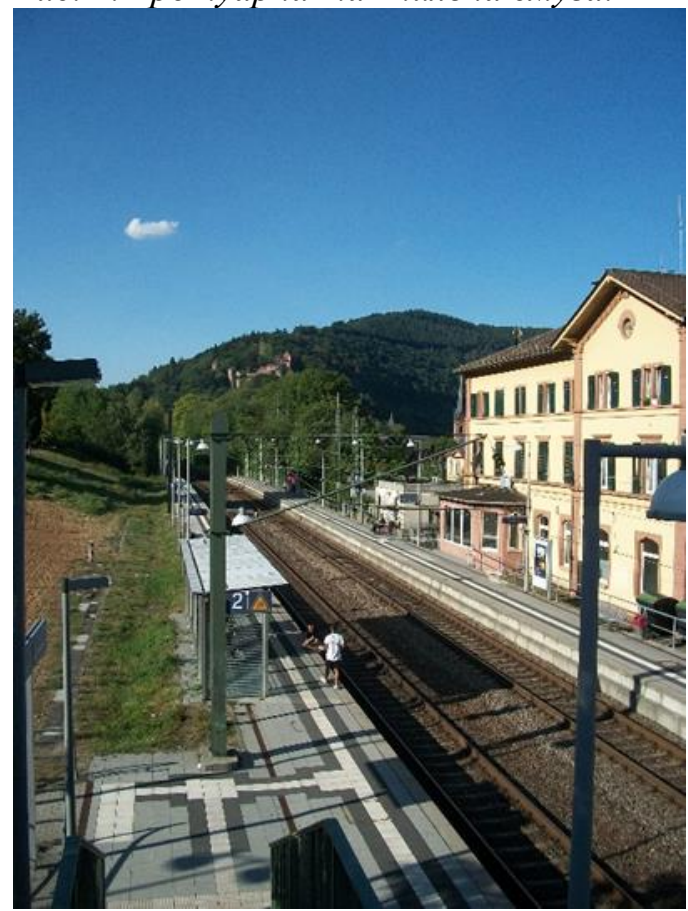

Рис. 2. Направляюча тактильна смуга

Залежно від призначення покажчики поділяються на дві групи:- попереджувальні (перед небезпечними ділянками, в місцях зміни напрямку руху, перед світлофорами і пішохідними переходами, перед вхо- 
дами в будівлю або підземний перехід) і направляючі (вздовж тротуарів, підземних переходів, перонів метро або залізничних станцій) (рис. 3) [8].

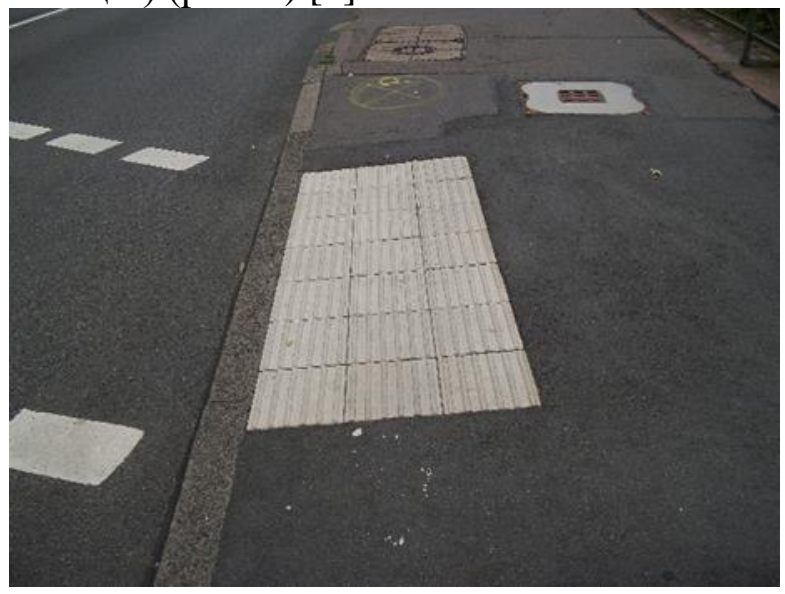

Рис. 3. Попереджувальна тактильна смуга.

Тактильні плитки виготовляють 3 кераміки, сталі, резини, бетону або керамограниту і на сьогоднішній день в Україні існує близько тридцяти фірм-виробників тактильної плитки.

Різниця між основним покриттям і тактильною смугою має становити не менше 30 люкс. Розмір таких плиток зазвичай: $400 \times 400 \times 8,5$ мм, $300 \times 300 \times 80 \quad$ мМ, $500 \times 500 \times 100$ мм. Водопоглинання становить не більш $0,02 \%$. Класс прочности -7 . Покриття має бути легким для прибирання снігу та бруду, тому матеріал повинен бути стійким до хімічних речовин $[6,9]$.

Застосування цього засобу структурує містобудівний простір, регламентує поведінку всіх учасників руху незалежно від віку, стану здоров'я, значно підвищує безпеку і комфортність пересування, що повністю відповідає концепції інклюзивного міста.

Важливим заходом згідно вимог стандартів «безбар'єрної» архітектури є пониження висоти бордюрних каменів в місцях перетину тротуару з проїжджою частиною до 4 см. При цьому бордюрний камінь фарбують в жовтий або білий колір $[6,10]$.

Якщо на вулиці передбачено додаткове обладнання (рекламні табло, таксофони, сміттєві корзини та ін.), слід розміщувати їх лінійно, при цьому нижня частина має знаходитись на висоті 0,7 м від тротуару, щоб слабозряча людина $з$ палицею могла оминути перешкоду.
Озвучені світлофори. В цьому році Центр безпеки дорожнього руху почав створювати стандарт звукового сигналу для світлофора. Акустичне обладнання і засоби інформації мають надавати допомогу особам з вадами зору, а також дублювати інформацію в найбільш людних місцях. До них належать: звукові маячки, шумові індикатори, засоби звуковідтворення, мовні синтезатори, та інші електроакустичні (звукопосилюючі) прилади. Не рекомендується розміщувати акустичні прилади так, щоб зони їхньої дії перекривали один - одного і створювали звукові перешкоди [11]. Слід розміщувати прилади в ніші або за екрани, що запобігають розповсюдженню відтворюваного сигналу в небажаному напрямку. Застосування таких приладів значно полегшує розповсюдження інформації в місцях 3 обмеженням візуальної орієнтації для всіх мешканців, незалежно від фізичних можливостей i, безперечно, підвищує рівень доступності середовища $[12,13]$.

Підземні переходи. В першу чергу потрібно забезпечити достатнє освітлення, оскільки люди зі послабленим зором можуть не помітити перешкод (рис. 4, 5). Крім того, сходи мають бути замарковані і облаштовані поручнями, а впродовж напрямку руху укладають направляючі тактильні смуги, а в точках зміни напрямку руху - попереджувальні.

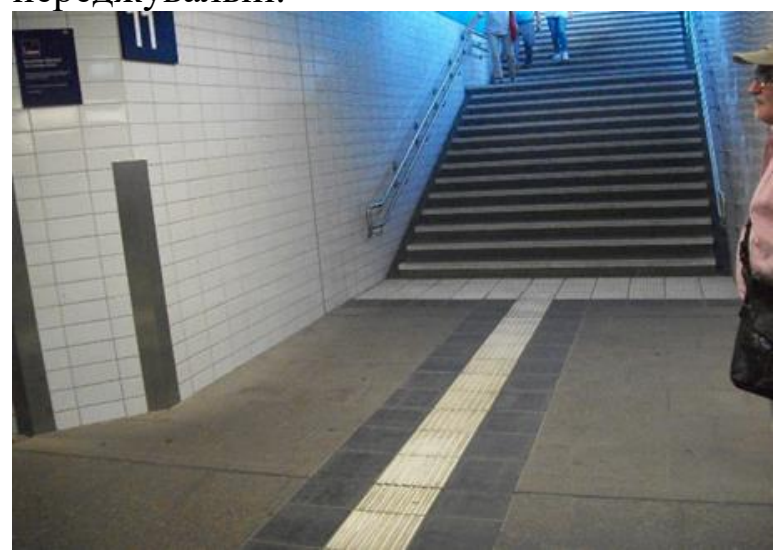

Рис. 4. Направляюча тактильна смуга. Підземний переход.

Часто підземні переходи обладнані електричними підйомниками чи ліфтами. Зона перед входом до такого ліфту повинна мати попереджувальну тактильну поверхню (рис. 6). 


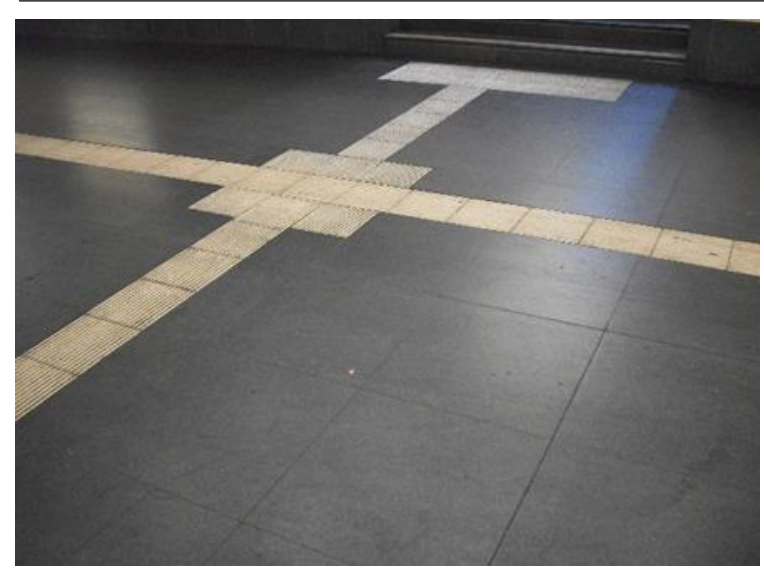

Рис. 5. Попереджувальна тактильна смуга. Підземний переход

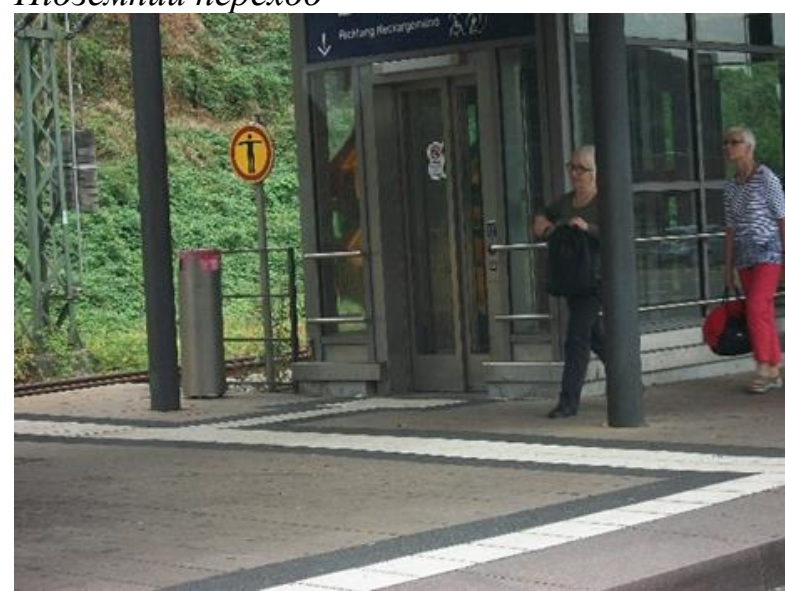

Рис. 6. Тактильна поверхня. Ліфт.

Сходи. Вхід з рівня землі (перепад висоти до 4 см.) - зручний для всіх . В випадках,коли необхідно використовувати сходи потрібно маркувати перш1у і останню сходини жовтою чи білою фарбою. Допускається також маркування краю всіх сходинок (рис. 7).

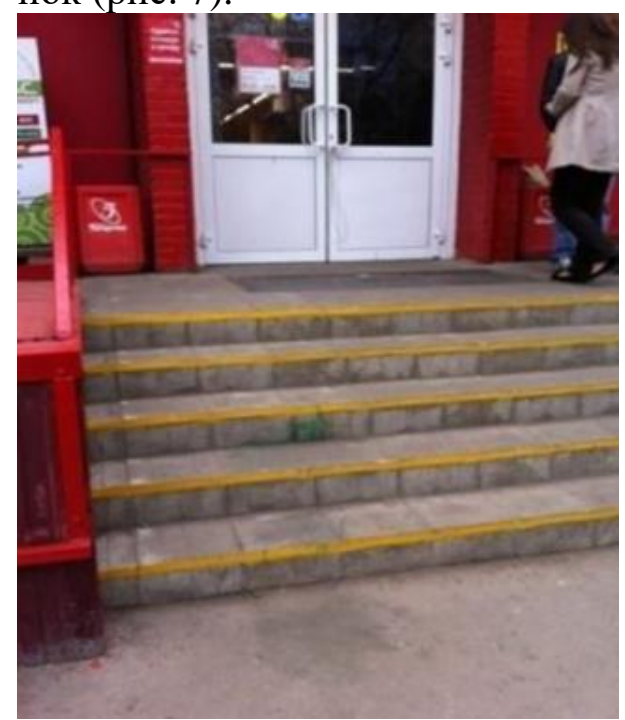

Рис.7. Вірне маркування сходів
Виділяти кольором всі сходи небезпечно, бо людина зі слабким зором не зможе визначити краю сходинки (рис. 8) [12, 14].

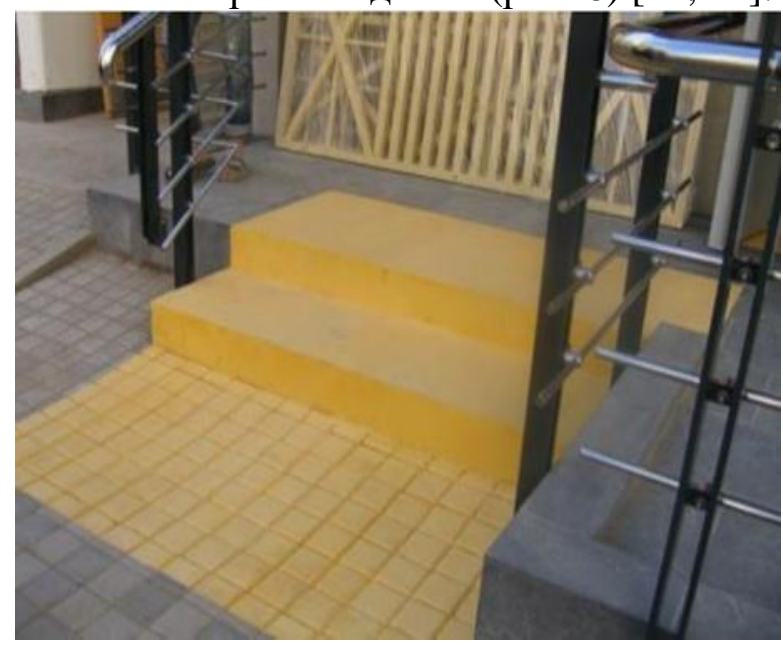

Рис. 8. Невірне маркування сходів

Особливу увагу слід приділити облаштуванню поручнів. Звичайно вони мають бути розташовані на висоті згідно діючим нормативам і але було б корисно розташування на них інформаційних таблиць шрифтом Брайля. Наприклад, на виході з метро або підземного переходу - назви і напрямки прилеглих вулиць, на залізничних станціях - розклад потягів і ін.

Наступним після першочергових засобів адаптації міського середовища до потреб людей з вадами зору є тактильні засоби інформації. Інформація щодо місця знаходження, попередження про небезпеку, розклад руху транспорту, режим роботи соціальних установ в близькому оточенні, надана на таблицях надрукованих шрифтом Брайля значно збільшить можливості для адаптації і підвищить комфортність життя.

Містобудівне середовище $є$ матеріальною структурою для функціонально-діяльностних процесів. Його структура віддзеркалює сукупність впливів матеріальної структури, специфічних вимог учасників соціального процесу і функціонального наповнення. Містобудівне середовище має забезпечити успішність i комфортність споживання для всіх. 
ЛІТЕРАТУРА:

1. Нарушение зрения и слепота [Электронный ресурс]. - Режим доступа: https://www. who.int/ru/news-room/fact-sheets/detail/blindness-and-visual-impairment

2. Моисеев Н.Н.- Алгоритмы развития.-М: Мир, 1974. - 304 с.

3. Діало Л.Т. Принципи формування архітектурного середовища інтер'єрів спеціалізованих дитячих дошкільних закладів. автореферат дисертаціi по ВАК 18.00.02, кандидат архитектуры [Электронный ресурс]/ - Режим доступа: https://revolution. allbest.ru/construction/00580215_0.html

4. Фоменко О.О., Данилов С.М. Когнитивнодослідницька матриця виявлення та аналізу проблем міста. Науковий вісник будівництва. - Харків: ХНУБА. - Том 93. - №3. - 2018. - C. 97-104.

5. Вхід вільний: інклюзивне місто [Электронный ресурс]. - Режим доступа: https://telegraf.design/vhid-vilnyj-inklyuzyvne-misto/

6. ДБН 2.2-17-2006. Доступність будинків і споруд для маломобільних груп населення.

7. Сафронов К.Э. Проблема современных городов - доступность транспортной инфраструктуры // Вопросы планировки и застройки городов. Материалы XV Международной науч.-практ. конф. / Под ред. проф. Ю.В. Круглова, доц. В.С. Глухова Пенза: ПГУАС, 2008. - С. 46-49.

8. СНиП 35-01-2001 Доступность зданий и сооружений для маломобильных групп населения.

9. Основи формирования доступной среды для инвалидов [Электронный ресурс]. - Режим доступа: http://www.culturechel.ru/Upload/ files/acc_envir/osnovy_dost_sredy.pdf.

10. Седых О.Г. Проблемы формирования безбарьерной среды для людей с ограниченными возможностями [Электронный ресурс]. - Режим доступа: https://cyberleninka.ru/search

11. Сафронов К. Э. Повышение эффективности процесса формирования доступной транспортной инфраструктуры в регионах [Электронный ресурс]. - Режим доступа: https://cyberleninka.ru/article/n/povyshenieeffektivnosti-protsessa-formirovaniya-dostupnoy-transportnoy-infrastruktury-vregionah
12. Прядко И. П. Проблемы проектирования жилищных моделей с учетом социальной адаптации маломобильных категорий населения к условиям жизни в современном городе [Электронный ресурс]. - Режим доступа: https://cyberleninka.ru/article/n/problemy-proektirovaniya-zhilischnyh-modeleys-uchetom-sotsialnoy-adaptatsii-malomobilnyh-kategoriy-naseleniy

13. Авербах М.Я. Брендування станцій харківського метрополітену. Погляд з позиції архітектора. Науковий вісник будівництва. Харків: ХНУБА. - Том 93. - №3. - 2018. C. 10-18.

14. Парфенов В. Г. Модель оценки эффективности социального проектирования безбарьерной среды для маломобильных граждан[Электронный ресурс]. - Режим доступа: https://cyberleninka.ru/article/n/modelotsenki-effektivnosti-sotsialnogo-proektirovaniya-bezbariernoy-sredy-dlya-malomobilnyh-grazhdan

\section{ШарЛай Е.В. РЕАЛИЗАЦИЯ КОНЦЕПЦИИ ИНКЛЮЗИВНОЙ СРЕДЫ В СФЕРЕ ГО- РОДСКИХ КОММУНИКАЦИЙ. В статье} приведены принципы создания создания инклюзивной среды и униварсального дизайна с целью обеспечения доступности доя всех слоев населения. Проанализированы методы организации городской средыдля адаптации людей с особыми потребностями преимущественно недостатками зрения. Приведены примеры зарубежного опыта обустройства городской среды согласно концепции инклюзивного города.

Ключевые слова: инклюзивный город, универсальный дизайн, адаптация, безбаръерная архитектура, доступность городской среды.

\section{Sharlay O.V. REALISATION OF CONCEPT OF INCLUSIVE ENVIRONMENT IN SPHERE OF URBAN COMMUNICATIONS.} In article following information is used: data about eye illness rate according to WHO. Inclusive environment \& universal design principles for providing availability for all layers of society are also given. Steps for setting up urban environment for people with special needs mainly with view disabilities adaptation are analysed. Examples of international experience of establishing urban environment according to inclusive city concept are given. Keywords: inclusive city, universal design, adaptation, borderless architecture, availability of urban environment. 